\title{
EFFECT OF DEFICIT IRRIGATION ON QUALITY INDICATORS OF APRICOT FRUITS AFTER HARVESTING AND STORAGE
}

\author{
L. Septar ${ }^{1 *}$, C. Moale ${ }^{1}$ C. Gavat ${ }^{1}$, I. Caplan ${ }^{1}$ and M. Stanca ${ }^{2}$ \\ 1 Research Station for Fruit Growing Constanța, Romania;
}

2 Research and Development Institute for Processing and Marketing of the Horticultural Products-Horting Bucharest, Romania

* Coresponding author email: septarleinar71@gmail.com

\begin{abstract}
Trees irrigation is one of the major activities because the fruit production is proportional to water use. The current decrease of water resources leads to the urgent need to adopt a strategy which could be applied to efficiently utilize water without affecting the growth, yield and fruit quality. Therefore, deficit irrigation is an alternative. The crop studied was apricot, 'Orizont' cultivar, 13 years old, grafted on the 'Constanta 14' rootstock. The planting distance was $4 \mathrm{~m}$ between the rows and 5 $m$ between trees on the row. The split-plot experiment described here is monofactorial with irrigation strategy having three graduations. The irrigation regime consists of a fully irrigated treatment (b1, non-stressed) according to the irrigation needs $(100 \%$ of ETc $=$ ETo $\times \mathrm{Kc})$, a deficit irrigation treatment (b2) irrigated with half the amount of water in b1 (50\% of ETc), and a control, non-irrigated treatment (b3). These plots comprised three adjacent fruit tree rows, with the central row containing five trees for measurements and observations. This research aims to study the effects of deficit irrigation on some quality indicators of apricot fruits after harvest and storage. Fruits in the b3 treatment were much firmer, followed by the fruits from the b2 treatment. The study suggests that moderate deficit irrigation can be profitable for enhancing key fruit quality characteristics.
\end{abstract}

Keywords: Prunus Armeniaca L., climate conditions, soil water potential, fruit firmness, ascorbic acid

\section{INTRODUCTION}

Drought is one of the main serious problems for fruit production. Therefore, improving water efficiency is a major goal for sustainable fruit growing. Deficit irrigation (DI) is a technique that irrigates the entire root zone with less evapotranspiration and leads to reduce the irrigation water use with maintaining farmers net profits (Hoffman et al., 1990). The effects of water deficit on fruit quality depend on the intensity and duration of the water stress period and on the sequence in which the water deficits occur, as well as on cultivar (Castel and Buj, 1990). In general, the fruit yield reduced in DI system by size and weight reduction of fruit, but quality parameters, such as sugars, ascorbic acid, and anthocyanin contents in fruit increased by water restrictions (Roccuzzo et al., 2014).

Apricot fruits are popular worldwide owing to their high nutritional value and delicious flavor, which not only can be used as fresh fruit but also has a high importance as processed product (Moradinezhad and Jahani, 2016). Fruits are not always consumed immediately 
after harvest and are therefore held in cold storage, refrigeration is widely used to delay ripening and control fruit decay (Goto et al, 2011). The ability to maintain fruit quality is defined in terms of appearance (color, absence of degradation signs or physiological diseases) and texture (firmness, juiciness).

This research aims to study the effects of deficit irrigation on some quality indicators of apricot fruits after harvesting and storage.

\section{MATERIALS AND METHODS}

Study area. The studied orchard is located in village Agigea (44을 $05^{\prime}$ Northern latitude and 28울 Eastern longitude), Dobrogea region, Romania. The experiment location has an average altitude of $30 \mathrm{~m}$ and is situated about $2 \mathrm{~km}$ from the Black Sea.The mean annual temperature in the Agigeavillage was $12.4^{\circ}$ Cand total annual rainfall was $489.6 \mathrm{~mm}$ (40year average, i.e. 1975-2015 period).

Experimental design and irrigation application.The split-plot experiment described here is mono-factorial with irrigation strategy having three graduations. The apricot tree (Prunus armeniaca L.) was selected for this study because is representative for this region. The biological material is representedby 'Orizont' cultivar omologated in 2004.

Climatic data were recorded by an automatic weather station (WatchDog Weather Station 2000, Spectrum Technologies Inc., Aurora Illinois, USA) by a 1-h step. These data were periodically transferred to a laptop and processed as diurnal means and used in calculations.

The soil is a calcaro-calcic chernozem (*World Reference Base for Soil Resources, 2006) with a loamy texture and alkaline $\mathrm{pH}$, a proper soil structure and high fertility in topsoil (0$60 \mathrm{~cm}$ ). Land slop is between 1.0 and $3.0 \%$ and soil bulk density around $1.20 \mathrm{~g} \mathrm{~cm}^{-3}$.

The study was carried out during two years $(2016 \div 2017)$. The fruit trees were planted in spring 2004, in a $4 \mathrm{~m} \times 5 \mathrm{~m}$ layout. The studied plots comprised three adjacent fruit tree rows with the central row containing five trees for measurements and observations. The canopy shape was a classic vase and the soil management systems was clean cultivation both between tree rows and in the row.The irrigation regime consisted of a fully irrigated treatment (b1) according to the irrigation needs (100\% of ETc = ETo x Kc, Penman-Monteith method, Allen et al., 1998) as previously described for the region by Paltineanu et al. (2007), a deficit irrigation treatment (b2) irrigated with half the amount of water in b1 $(50 \%$ of ETc), and a control, non-irrigated treatment (b3). Irrigation application was usually carried out in b1 when soil water content (SWC) was about to reach the mid-interval between field capacity (FC) and wilting point (WP). The watering method used was drip irrigation. The dripper spacing was $0.6 \mathrm{~m}$ and the dripper discharge about $2.0 \mathrm{Lh}^{-1}$. The irrigation period lasted from July to August in 2016 and June to September in 2017.In 2016, we applied just four watering, with $20 \mathrm{~mm}$ in b1 and $10 \mathrm{~mm}$ in b2, totaling $80 \mathrm{~mm}$ in b1 and $40 \mathrm{~mm}$ in b2, respectively. However, there were nine irrigation applications during the dryer period in 2017 each of $20 \mathrm{~mm}$ in b1 and $10 \mathrm{~mm}$ in b2, totaling $180 \mathrm{~mm}$ and $90 \mathrm{~mm}$, respectively. No water was applied in b3.

Soil water content measurements.Soil water matric potential (SWP) was measured with Watermark resistance blocks (6450 Watermark Soil Moisture Sensor) installed for each fruit tree at four depths: 20,40,60 and $80 \mathrm{~cm}$ at a $150 \mathrm{~cm}$ distance from the tree trunk. The sensors were placed on the same vertical line at $45^{\circ}$ angles below horizontal according to the method described by Paltineanu and Howse (1999). These data were recorded by WatchDog dataloggers (WatchDog Model 1650 Data Logger, Spectrum Technologies) and 
downloaded periodically by a laptop. The relationships between SWP measured with the Watermark sensors and SWC measured gravimetrically were previously determined from field data (Paltineanu et al., 2011b); these relationships were then used to transform soil water matric potential readings into SWC values during the experiment.

Fruits and determining fruit quality. Apricot fruits were obtained at the Research Station for fruit Growing (RSFG) Constanța, located in Agigea, Romania, in a conventional orchard. Apricots were harvested in the first 10-day periodof July. After harvesting and storage (warm storage: 7 days at $18-20^{\circ} \mathrm{C}, 70 \%$ relative humidity; cold storage: 14 days at $10-12^{\circ} \mathrm{C}$ and $4-6^{\circ} \mathrm{C}, 90 \%$ relative humidity), firmness measurements, dry soluble substance and ascorbic acid (vitamin C) were made at fruits in the treatments studied (Figure 1). Measurements were carried out ina number of five fruit/treatment, each fruit being penetrated in three points in the equatorial zone. Firmness determination was carried out with OPD table penetrometer, measuring the penetration depth of the conical needle into the fruit pulp expressed in penetrometer units $(1 \mathrm{UP}=0.1 \mathrm{~mm})$. The soluble solids concentration has been determined by refractometry. The refractive index of the product is influenced by the presence of other solutes, for example, organic acids, minerals and amino acids. Determination of ascorbic acid (vitamin C) is based on the extraction of the sample with oxalic acid and titrating with 2.6 dichlorophenol indophenol in excess.

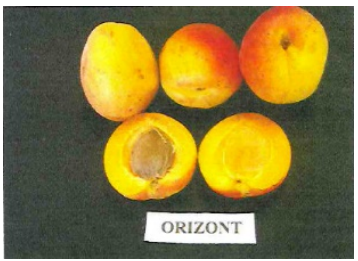

a)

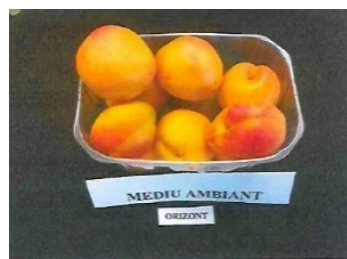

b)

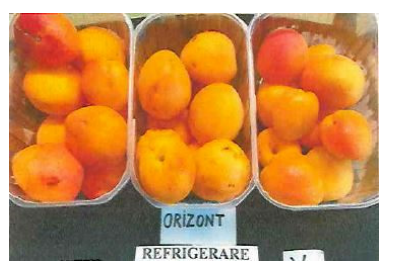

c)

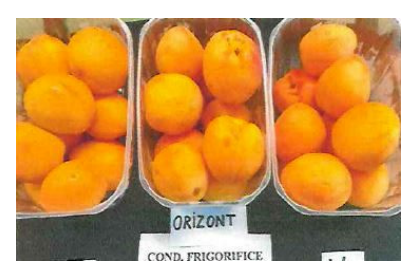

d)

Figure 1. Fruits after harvesting and storage: a) After harvesting, b) Warm storage at $18-20^{\circ} \mathrm{C}$,

c) Cold storage at $10-12^{\circ} \mathrm{C}$ and d) Cold storage at $4-6^{\circ} \mathrm{C}$

Data analyses. SPSS 14.0 software and Microsoft Office Excelwereused for the analysis of variance and various calculations for fruit quality properties. Different letters in the graphs indicate significant differences for the probability $(\mathrm{P}) \leq 0.05$ according to Duncan`s multiple range test.

\section{RESULTS AND DISCUSSIONS}

Climate conditions.For experimental period $(2016 \div 2018)$, the monthly average air temperatures ranged from 13.7 to $25.1^{\circ} \mathrm{C}$ from April to September, with mean air temperature value of $20.5^{\circ} \mathrm{C}$. No relevant temperature variations were recorded compared with mean multiannual of the area, $19.6^{\circ} \mathrm{C}$, respectively (Table 1 ). Climatic data were recorded by an own automatic weather station (WatchDog Weather Station 2000, Spectrum Technologies Inc., Aurora Illinois, USA).

In the study period, the mean annual rainfall amount was $191.2 \mathrm{~mm}$, versus $272.9 \mathrm{~mm}$ for long-term (Table 2). The period of experiment $(2016 \div 2018)$ was considered as a relatively normal period, showing however atendency of soil moisture depletion. 
Table 1. Mean, maximum and minimumair temperature $\left({ }^{\circ} \mathrm{C}\right)$ from April to September over a 3-years period versus the long-term, $1975 \div 2015$

\begin{tabular}{|c|c|c|c|c|c|c|c|}
\hline \multirow[b]{2}{*}{ Climatic element } & \multicolumn{7}{|c|}{ Air temperature values from 3 years period $(2016-2017-2018),{ }^{\circ} \mathrm{C}$} \\
\hline & April & May & June & July & August & September & $\begin{array}{l}\text { Mean for } \\
\text { April- } \\
\text { September } \\
\text { period }\end{array}$ \\
\hline Mean air temperature, $\mathrm{T}_{\text {med }}\left({ }^{\circ} \mathrm{C}\right)$ & 13,7 & 18,4 & 21,8 & 23,9 & 25,1 & 20 & 20,5 \\
\hline Mean maximum air temperature, $\mathrm{T}_{\max }\left({ }^{\circ} \mathrm{C}\right)$ & 21,3 & 25,3 & 28,7 & 29,8 & 32,9 & 27 & 27,5 \\
\hline Mean minimum air temperature, $T_{\text {min }}\left({ }^{\circ} \mathrm{C}\right.$ & 6,1 & 11,5 & 14,8 & 18 & 17,3 & 13 & 13,5 \\
\hline $\begin{array}{l}\text { Mean multiannual temperatures }\left({ }^{\circ} \mathrm{C}\right) \\
(40 \text {-year average, i.e. } 1975-2015 \text { period) }\end{array}$ & 10,9 & 16,5 & 20,8 & 25,1 & 24,5 & 19,9 & 19,6 \\
\hline
\end{tabular}

Table 2. Cumulative rainfall $(\mathrm{mm})$ from April to September over a 3-years period versus the long-term, $1975 \div 2015$

\begin{tabular}{|c|c|c|c|c|c|c|c|}
\hline \multirow[b]{2}{*}{ Climatic element } & \multicolumn{7}{|c|}{ Rainfall values from 3 years period (2016-2017-2018), $\mathrm{mm}$} \\
\hline & April & May & June & July & August & September & $\begin{array}{l}\text { Mean for } \\
\text { April- } \\
\text { September } \\
\text { period }\end{array}$ \\
\hline Rainfall, R (mm) & 16,4 & 44,4 & 56,9 & 63,5 & 9,2 & 0,8 & 191,2 \\
\hline $\begin{array}{l}\text { Mean multiannual rainfall }(\mathrm{mm}) \\
(40 \text {-year average, i.e. } 1975-2015 \text { period) }\end{array}$ & 33 & 46 & 43,3 & 65,5 & 42,6 & 42,5 & 272,9 \\
\hline
\end{tabular}

Soil water content (SWC) during in irrigation period. In 2016, following the application of four watering, the dynamics of soil water content is illustrated in Figure 2. As in previous years, SWC values in both $\mathrm{b} 1$ and $\mathrm{b} 2$ varied between $\mathrm{FC}$ and management allowed depletion (MAD). After applying the last watering, the SWC values were closer to FC. In b3, SWC values were within thehalf interval between MAD and WP.

In 2017, following the application of nine irrigation applications, the dynamics of soil water content is illustrated in Figure 3. In the irrigated treatments, the SWC values oscillated in the range between FC and MAD, the SWC values of b1 being much closer to FC. In b2, SWC values were to half interval between FC and MAD, with values closer to MAD in the $80 \mathrm{~cm}$ depth.In b3, SWC values were within thehalf interval between MAD and WP, with values approaching to WP at the end of growing season.

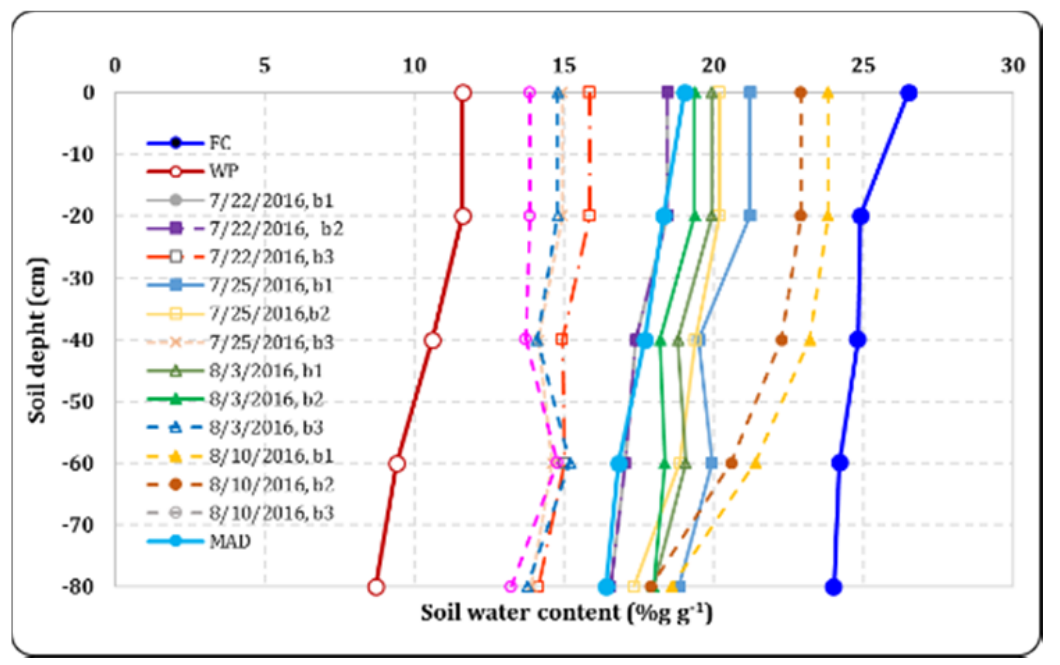

Figure 2. Soil water content (SWC) in experimental plot, Agigea village, Dobrogea- 2016 


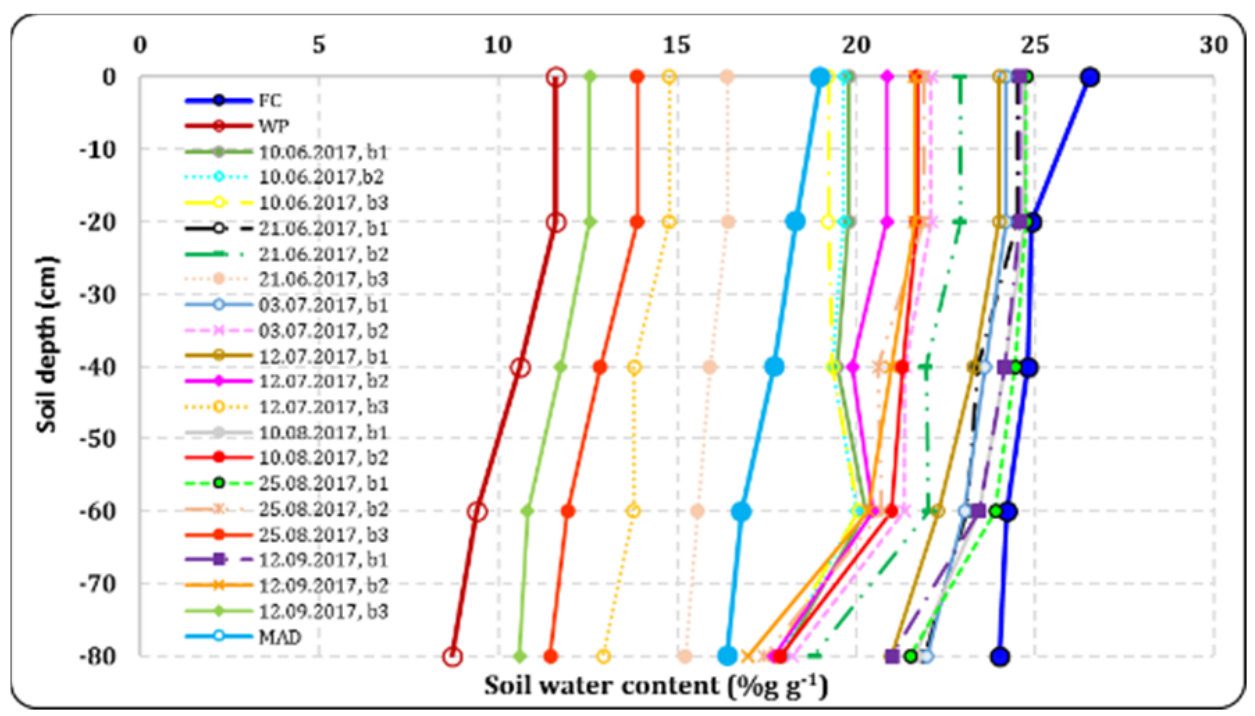

Figure 3. Soil water content (SWC) in experimental plot, Agigea village, Dobrogea-2017

\section{Determining fruit quality after harvesting and storage.}

After harvesting and storage, the fruits of experience havebeen subjected to firmness measurements, dry soluble substance and ascorbic acid (vitamin C). After harvesting, apricots had a firmness of 98.89 UP to 109.54 UP (figure 4).After warm storage, apricot fruits had a firmness of 137.80 UP to $154.65 \mathrm{UP}$, after cold storage, at $10-12^{\circ} \mathrm{C}$, apricots had a firmnees of 137.05 UP to 158.70 UP and after cold, at $4-6^{\circ} \mathrm{C}$, apricot fruits had a firmness of 123.70 UP to 153.65 UP (figures 5, 6 and 7).

Fruits in the b3 treatment were much firmer, followed by the fruits from the b2 treatment. The smallest firmness was found in b1 treatment.

Figures 4-7 show that there were significant differences between the treatments studied on fruit's fermity, as indicated by different letters accoring to the probability $(\mathrm{P}) \leq 0.05$ according to Duncan`s multiple range test.

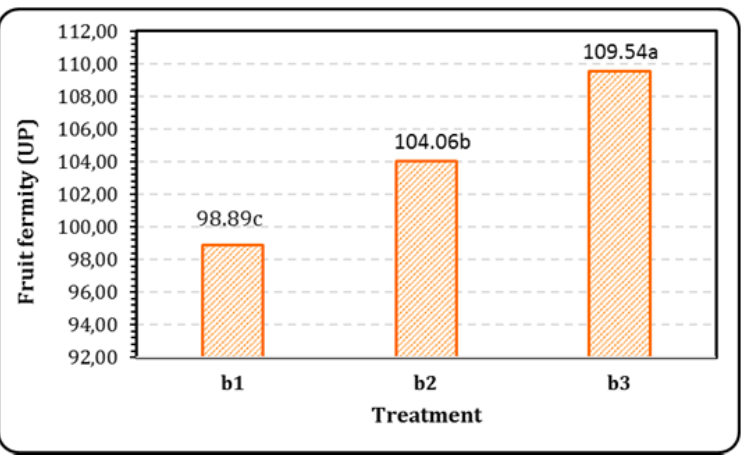

Figure 4. Apricot fruit fermity after harvesting, 2016-2017 period (mean values)

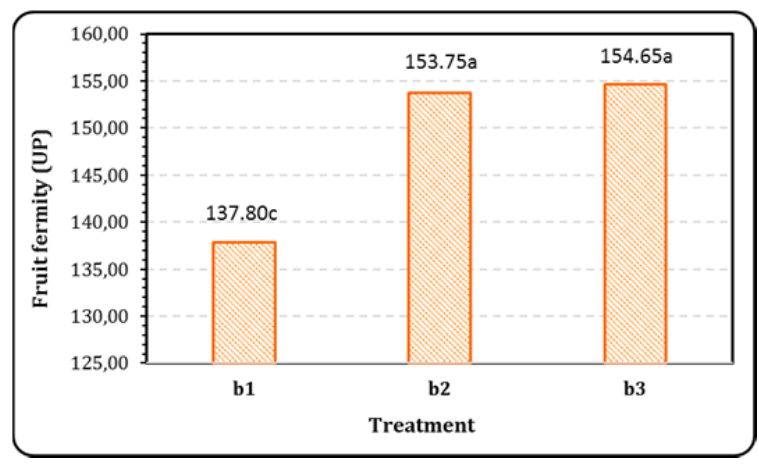

Figure 5. Apricot fruit fermity after warm storage, 2016-2017 period (mean values) 


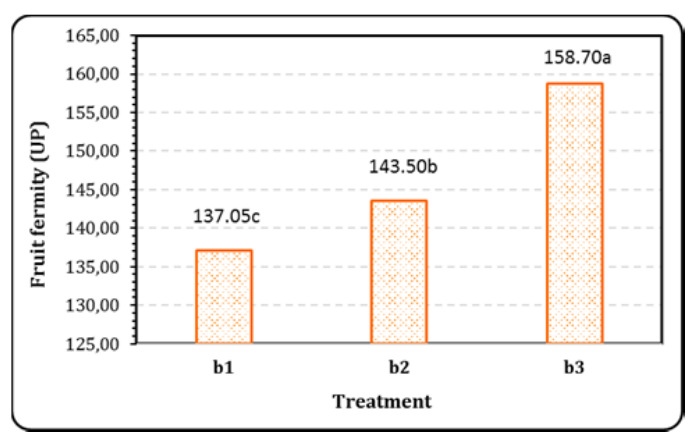

Figure 6. Apricot fruit fermity after cold storage at $10-12^{\circ} \mathrm{C}, 2016-2017$ period(mean values)

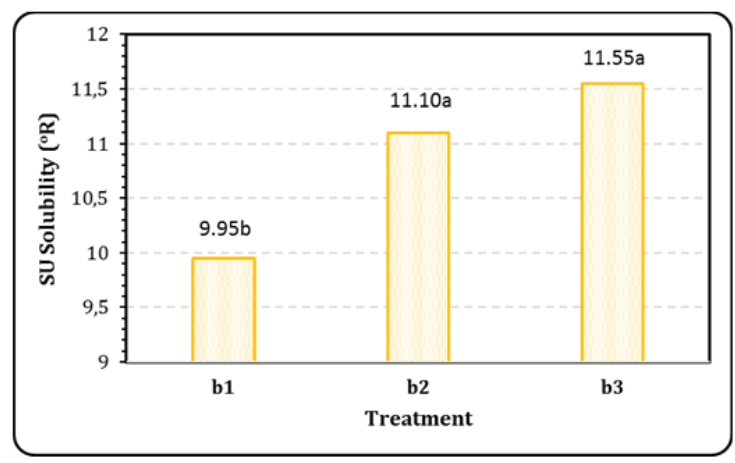

Figure 8. SU Solubility for apricot fruits after harvesting, 2016-2017 period(mean values)

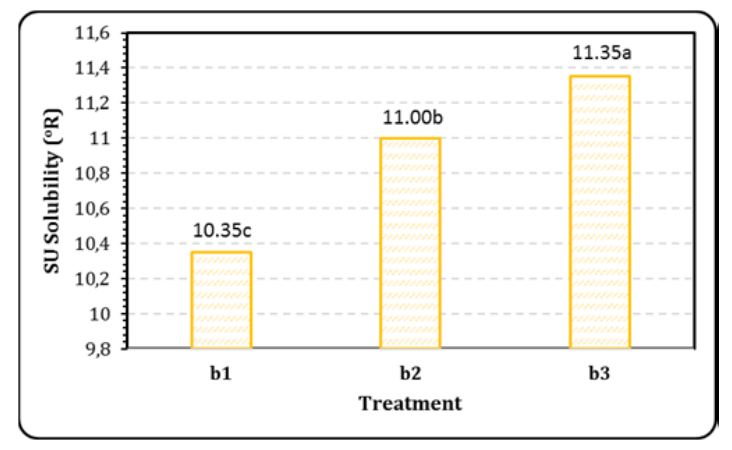

Figure 10. SU Solubility for apricot fruits after cold storage at $10-12^{\circ} \mathrm{C}, 2016-2017$ period(mean values)

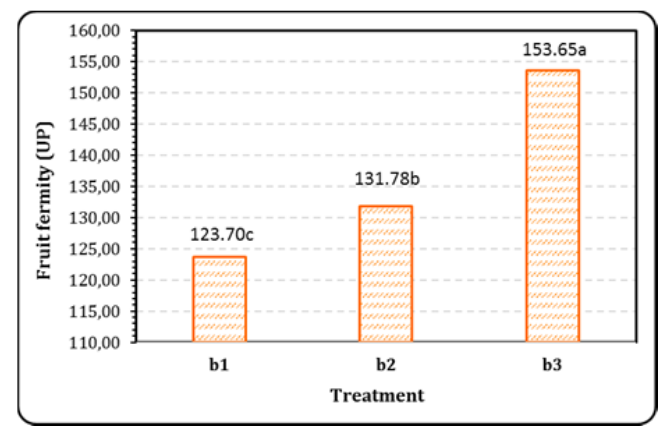

Figure 7. Apricot fruit fermity after cold storage at $4-6^{\circ} \mathrm{C}, 2016-2017$ period(mean values)

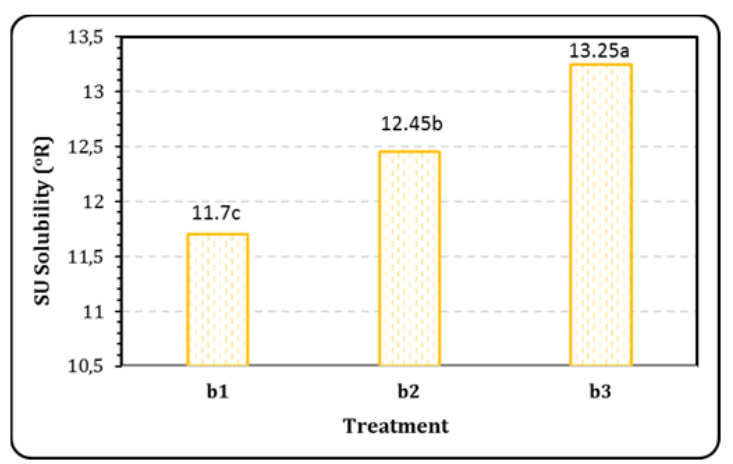

Figure 9. SU Solubility for apricot fruits after warm storage, 2016-2017 period(mean values)

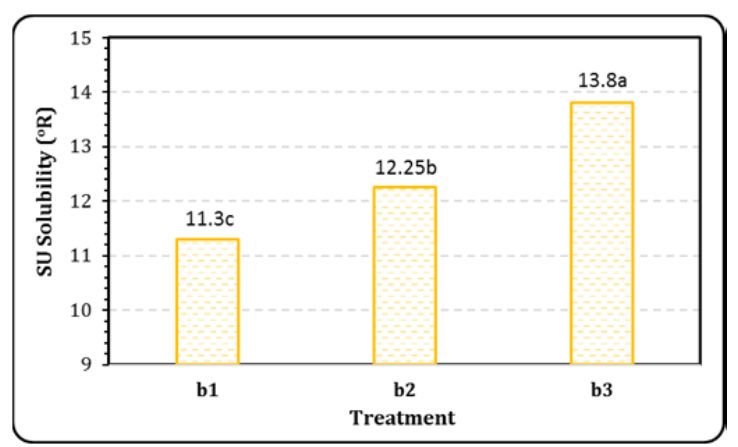

Figure 11. SU Solubility for apricot fruits after cold storage at 4- $6^{\circ} \mathrm{C}, 2016-2017$ period(mean values)

As with fruit fermity, the dry soluble matter determined on the fruits of the studied treatments had the same trend. After harvesting, the highest value was obtained in b3 treatment, $11.55^{\circ} \mathrm{R}$ and the lowest value in b1 treatment, $9.95^{\circ} \mathrm{R}$, respectively (figure 8). After storage, the highest value was obtained in b3 treatment, $13.8^{\circ} \mathrm{R}$-after cold storage at 4- ${ }^{\circ} \mathrm{C}$ (figure 11 ) and the lowest value in b1 treatment, $10.5^{\circ} \mathrm{R}$ - after cold storage at $10-12{ }^{\circ} \mathrm{C}$ (figure 10), respectively.

Figures 8-11 show significant differencesbetween the treatments studied regarding the dry soluble matter of the fruits. 


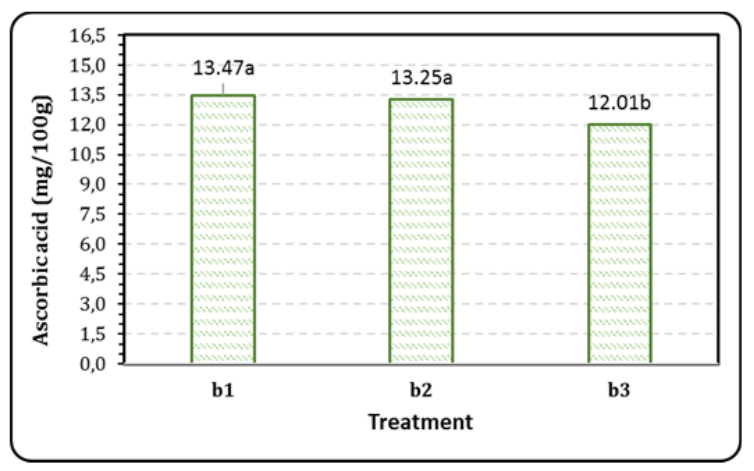

Figure 12. Ascorbic acid for apricot fruit after harvesting, 2016-2017 period(mean values)

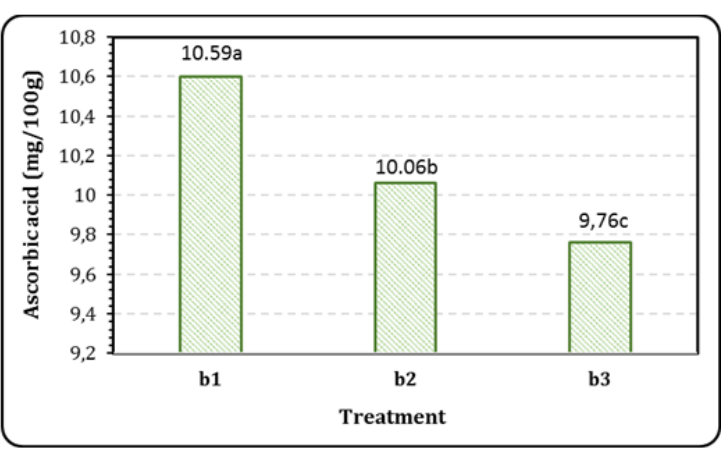

Figure 14. Ascorbic acid for apricot fruit after cold storage at $10-12^{\circ} \mathrm{C}, 2016-2017$ period(mean values)

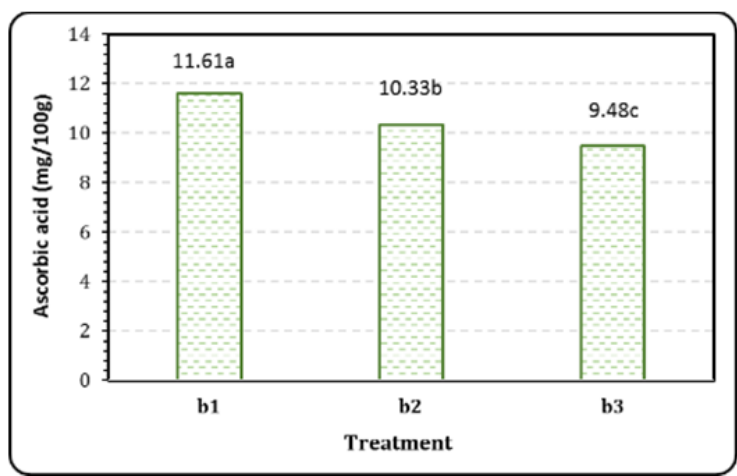

Figure 13. Ascorbic acid for apricot fruit after warm storage, $2016-2017$ period(mean values)

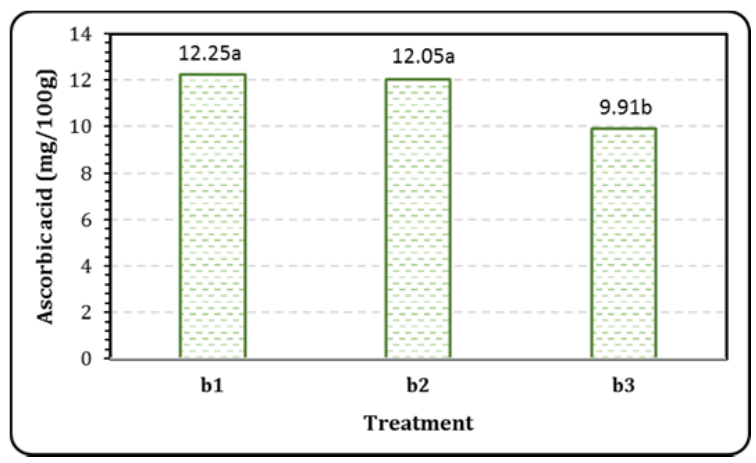

Figure 15. Ascorbic acid for apricot fruit after cold storage at $4-6^{\circ} \mathrm{C}, 2016-2017$ period(mean values)

Figures 12-15 show the values of ascorbic acid (vitamin C) of the fruits in the studied treatments. Even if the differences between the treatments were not large, they were signifficantly different; this finding emphasizes again the positive effect of irrigation application in apricot orchards, even if was applied as deficit irrigation.

\section{CONCLUSIONS}

Apricots are climateric fruits whose properties declined rapidly after harvest.Therefore, it is recommended to store them in certain environmental conditions in order to maintain fruit quality.

Following the study, the highest values for fruit firmness and dry solubility were obtained in non-irrigated treatment (b3) and in the deficit irrigation treatment (b2), both after harvesting and storage.

In the case of ascorbic acid (vitamin C) of fruits, even if the differences between treatments were not large, they were significantly different, which again emphasizes the positive effect of irrigation in apricot orchards.

Deficit irrigation technique in fruit orchards are indispensable need for preserving tree qualitywater saving and maintaining high the fruit quality. 


\section{REFERENCES}

1. Allen, R.G., Pereira, L., Raes, D., and Smith, M. (1998). Crop evapotranspiration- Guidelines for computing crop water requirements. FAO Irrig. and Drain. Paper 56, Rome, Italy, p. 301. https://appgeodb.nancy.inra.fr/biljou/pdf/Allen_FA01998.pdf

2. Castel, J. R., and Buj, A. (1990). Response of Salustiana oranges to high frequency deficit irrigation. Irrig. Sci. 11, 121-127. https://link.springer.com/article/10.1007/BF00188448

3. Goto,M., Minamide,T. and Iwata,T.(2011). Influence of cultivars and harvest maturity on the chilling sensitivity and on the effect of cold-shock treatment for preventing the chilling injury in Mume Uapanese apricot Prunus mume Sieb. et Zucc.) fruits. Journal of Japanese Institute of Cold Chain, vol. 12 (1), 17-24.

4. Hoffman, G.J., Towell, T.A. and Solomon, K.H. (1990). Management of farm irrigation systems. ASAE, St. Joseph, MI, USA. https://eprints.nwisrl.ars.usda.gov/805/1/733.pdf

5. Moradinezhad, F. and Jahani, M. (2016). Quality improvement and shelf life extension of fresh apricot fruit (Prunus Armeniaca cv. Shahroudi) using postharvest chemical treatments and packaging during cold storage. International Journal of Horticultural Science and Technology, vol. 3 (1), 9-18.

6. Paltineanu, Cr., Mihailescu, I.F., Seceleanu, I., Dragota, C.,, and Vasenciuc, F. (2007). Using aridity indexes to describe some climate and soil features in Eastern Europe: a Romanian case study. Theoretical and applied climatology, Springer Velag Vienna, Volume $90 \quad$ (3-4), 263-274. https://link.springer.com/article/10.1007\%2Fs00704-007-0295-3.

7. Paltineanu, C., Septar, L., Moale, C., Oprita, A., and Lamureanu, G., (2011b). Peach irrigation under soil water stress in the south-eastern part of Romania. Acta Horticulturae 922, 195-202. https://www.actahort.org/members/showpdf?booknrarnr=922_25\&session=29159\&justloggedin=2

8. Roccuzzo, G., Villalobos,F. J., Testi,L. and Fereres, E.(2014). Effects of water deficits on whole tree water use efficiency of orange. Agricultural Water Management, Volume 140, 61-68.

9. World Reference Base for Soil Resources (2006). A framework for international classification, correlation and communication. Food and Agriculture Organization of the United Nations, Rome, p. 145 http://epic.awi.de/35324/1/wsrr103e.pdf 